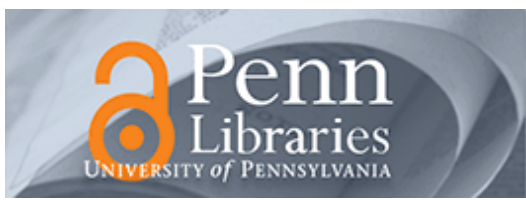

University of Pennsylvania
ScholarlyCommons

Departmental Papers (Classical Studies)

Classical Studies at Penn

1998

\title{
Reading Latin in Schools and Colleges
}

Joseph Farrell

University of Pennsylvania, jfarrell@sas.upenn.edu

Follow this and additional works at: http://repository.upenn.edu/classics_papers

Part of the Classics Commons

\section{Recommended Citation}

Farrell, J. (1998). Reading Latin in Schools and Colleges. The Classical World, 92 (1), 21-26. http://dx.doi.org/10.2307/4352179

This paper is posted at ScholarlyCommons. http://repository.upenn.edu/classics_papers/121

For more information, please contact repository@pobox.upenn.edu. 


\title{
Reading Latin in Schools and Colleges
}

\begin{abstract}
Years ago, when I began studying Latin, I did not intend to become a student of literature. Nevertheless, that is what happened, and my way of reading literature-any literature-is always informed by my interest and training in Latin and Greek. The same is, of course, not necessarily true either of all classicists (whose main interests may not be accurately described as "literary") or of all readers (who may not even know Latin or Greek)-and I try not to behave as if it should be! But there is no getting entirely away from the business of reading, and as both a teacher of classics and a teacher of literature, I have an enormous professional concern with how students are taught to read. In my own experience, viewed in hindsight, the apparent progression from the study of Latin and Greek as languages (which, of course, never actually concludes) to the study of Latin and Greek as literature looks so natural as to appear inevitable. It is, however, anything but, and for me or anyone involved in running an educational program at any level to assume otherwise would be a big mistake. That is a relatively simple point. A more subtle one, perhaps, is this: our professional failure to take this point seriously helps to explain some of the disjunctions that exist between high school and undergraduate classics programs, including the perplexing tendency of students with strong high school classics backgrounds not to continue these studies in their college and university careers.
\end{abstract}

\section{Disciplines}

Arts and Humanities | Classics 


\section{READING LATIN IN SCHOOLS AND COLLEGES}

Years ago, when I began studying Latin, I did not intend to become a student of literature. Nevertheless, that is what happened, and my way of reading literature - any literature-is always informed by my interest and training in Latin and Greek. The same is, of course, not necessarily true either of all classicists (whose main interests may not be accurately described as "literary") or of all readers (who may not even know Latin or Greek)-and I try not to behave as if it should be! But there is no getting entirely away from the business of reading, and as both a teacher of classics and a teacher of literature, I have an enormous professional concern with how students are taught to read. In my own experience, viewed in hindsight, the apparent progression from the study of Latin and Greek as languages (which, of course, never actually concludes) to the study of Latin and Greek as literature looks so natural as to appear inevitable. It is, however, anything but, and for me or anyone involved in running an educational program at any level to assume otherwise would be a big mistake. That is a relatively simple point. A more subtle one, perhaps, is this: our professional failure to take this point seriously helps to explain some of the disjunctions that exist between high school and undergraduate classics programs, including the perplexing tendency of students with strong high school classics backgrounds not to continue these studies in their college and university careers.

To illustrate the point, let us consider how Latin literature is studied, first from the perspective of a high school student, then from that of an undergraduate.

In secondary schools, Latin is taught by and large as a foreign language rather than as literature. The traditional elementary sequence of grammar, Caesar, and Cicero reveals an almost antiliterary perspective. Caesar obliges students with a repetitive style and affords excellent opportunities to drill the ablative absolute, indirect discourse, and other characteristically Latinate constructions. Cicero is read for purity of diction, correctness of grammar, and a pronounced tendency towards fulsome elaboration of the hypotactic complexities possible in a highly inflected language. Neither author produced the kind of literature that teenagers would read anyway if it were up to them (as if!). Both can be and are read in colleges and universities in some surprisingly unexpected literary ways; but to my knowledge, readings of gendered space in the Gallic Wars have yet to find their way into many secondary school curricula. Only in the later years do high school students really begin to read Latin as literature, which in practice means reading poetry; but even then linguistic competence is still emphasized much more than literary competence. High school Latin is, in this respect, not so very different from French, German, or Spanish. The purpose of studying a foreign language, especially in the early years, is to teach systematic, logical thinking, to develop the memory, to sharpen the student's ability to under- 
stand and use languages in general (but particularly one's own), and to impart a certain amount of "cultural literacy" as well. If Latin has an educational advantage over other languages, that is because it is even more foreign than they, is more systematic, and, not incidentally, has been used as more or less just this kind of educational tool for nearly two thousand years. But in a modern high school Latin curriculum, the primary focus is seldom, if ever, really on reading literature; that is one of the jobs of the English department.

While there are more and less successful high school Latin programs, by and large they all seem to accomplish what they set out to do: they develop basic cognitive skills in a way that makes students better learners. With the benefit of this training, high school Latin students generally test well and become high achievers in the less structured environment of undergraduate education, where their task is no longer to develop basic cognitive skills but to acquire a certain breadth of intellectual experience through general course work and to hone their critical faculties by means of intensive concentration on a major subject. There is abundant evidence to suggest that students who have studied Latin in high school generally make a successful transition to this new type of learning and do well at college or university. But one thing these students do not do, at least not in great numbers, is go on to study classics as undergraduates.

Before asking why, let us consider the structure of a typical undergraduate classics program. Right away the word "typical" lands us in trouble. But if our aim is to describe a program that satisfies all of its principal constituencies, this program will offer courses in Latin and Greek from a beginning through an advanced level along with courses in ancient history, archaeology and art history, classical mythology, other courses on classical civilization in varying configurations, and literature in translation. Because so few students do continue their high school Latin or Greek, the program will be designed to accommodate students with little or no prior knowledge of either language; possibly students who love classics, but who have no great interest or aptitude for language study; certainly students whose interest in classics is more historical or archaeological than literary; and also those students who have had sustained linguistic training in traditional high school programs and who do want to continue. It is clear why the word "typical" will not do; few departments can really meet all these needs, and many, in order to avoid failing all their constituencies, understandably focus on the needs of only one or two.

For the moment, then, let us suppose that our hypothetical department has decided to concentrate its efforts on developing a major program accessible to students with no prior experience in the ancient languages - a sensible and probably even unavoidable strategy in today's academic marketplace. Such a program might require a student to study little or no Latin or Greek; it might also, if suffi- 
cient resources were available, try to provide a parallel program for students who want to study one or both languages from the alphabet onwards. Obviously such a program cannot be designed with a class of students who studied the language for four or five years in high school primarily in mind. In fact, an undergraduate program in Latin intended for students with no previous experience in the language might actually look a lot like a high school Latin program-superficially, at least. But its aims and, therefore, its approach to the materialincluding the ways in which it taught students to read literaturewould be very different.

First of all, an undergraduate classics program has to move fast. Four years race right by, and if the students are to have the intellectual experience that they deserve, they have to get out of the grammar book quickly. This means that material that might have occupied four years of their high school careers must be covered in no more than two. It is not the case that we learn languages more quickly at this age (if anything, the opposite is true), but the linguistic training of a traditional secondary school Latin program is not generally thought to be suitable to stand by itself as the content of an undergraduate major. So it is necessary to move through the elementary phase of the program quickly in order to enable the students to do advanced work.

Even so, no program can afford to treat elementary language courses as mere remedial work that ought to have been done in high school; they must be, to the fullest extent possible, college and university courses in their own right. This generally means supplementing the basic grammatical textbook with the most interesting readings available and presenting that material in the most interesting way. One way of doing this is to sample the variety of reading strategies that classical texts will support. It would be an exaggeration to say that undergraduate Latin I and Greek I classes have become seminars on literary interpretation; but I believe it is the case that college and university programs begin to incorporate principles of literary interpretation into language courses earlier than do comparable high school courses. It is here that a student might encounter gendered space in the Gallic Wars, for instance, along with a first exposure to implied indirect discourse. These momentous events might take place in the third or even the second semester of elementary study. Similarly, an undergraduate might encounter the Aeneid in the third or fourth semester rather than in the fourth or fifth year; and the poem will look rather different from how it does to a high school junior or senior.

The difference will have a lot to do with how the students approach the text and with the questions that they are encouraged to ask. For most high school students, the instructor is the student's principal source of information about the various contexts-historical, literary, mythological, and so forth-in which the text is read. Even if the instructor bends over backwards to convince the students that the relationship between any text and its various contexts is far 
from simple and that widely varying interpretations of the text's meaning are possible, it is probably impossible at this level to avoid a certain amount of objectification of the business of reading. And in teaching younger students, some objectification is both necessary and desirable. For more mature students, however, greater benefits are realized from confronting more fully the complexities of the textual condition.

This is true not only for literary interpretation but for more basic elements of reading as well. High school texts never come equipped with an apparatus criticus. Students are usually told something about the manuscripts on which our printed texts depend, but few teachers make much of the fact that experts regularly disagree over what text to print in the first place. By the same token, the rules of grammar are not presented as a matter of approximation or debate; they exist to solve problems, not to deepen the complexity of the reading process. Undergraduates, of course, especially beginners, do not concentrate on textual variants and grammatical cruces, but an undergraduate Latin or Greek major would have little intellectual integrity if it did not deal with these issues to some extent, and it would be strange and duplicitous to try to conceal them from the students one year, only to begin acknowledging their existence the next. In fact, one of my favorite teaching texts, R. G. Austin's commentary on Cicero's Pro Caelio, graphically illustrates how Austin changed his mind on a number of grammatical points in the course of issuing three separate editions of his commentary, and one of the reasons I use it is that it gives me the opportunity of discussing this issue with my students. But I doubt whether I would attempt the same thing with high schoolers, or at least whether I would make such a point of it.

The same principle holds for other kinds of reading. It is important that a high school student understand that the Aeneid is formally a panegyric of Augustus and his regime, and that interpretation of the poem along these lines has played a major role in the development of subsequent European culture. To the extent that one can go beyond this basic view to explore the complexities of the poem as (in my view) a rather pessimistic meditation on the human condition (and a fortiori on Augustus' regime), I would argue for doing sothough not at the expense of the students' ability to appreciate the poem on a more basic level. With college or university students, however, I would feel compelled to stress certain elements of indeterminacy and internal contradiction in the poem, though not without acknowledging that there are responsible scholars who do not share my views. Here one should try to take advantage of the added sophistication and experience as readers that undergraduates ought to have over high school students. And to repeat, this is why they have come to college: to be challenged to think about complex issues of just this sort, and not just about how to construe sentences from a foreign tongue.

The differences outlined above are real: they should not be underestimated, but neither should they be exaggerated; and so I return 
to the issue of continuity, or the lack thereof. Why is it that so few students who study Latin in high school go on to study classics in college? I have no ready answer, but I do have some ideas. The causes may be contradictory. Obviously I have painted a picture of two rather different approaches to teaching similar material. If most undergraduate classics students were actually continuing what they had begun in high school, the situation might be different. Then again, it might not. The study of Latin in high school has been constructed for so many generations as a kind of mental gymnasium appropriate to the young, and it has served this purpose so well that it may be hard for students to think of it in any other way. A high school senior who is about to leave behind four years of Latin, possibly taken as a requirement instead of by choice, is likely to have one of two reactions. The first would be a desire to put aside the things of youth and take some courses suitable for a young adult. Such a student might be making a big mistake, since undergraduate classics courses really aren't the same thing as the ones being left behind in high school; but many students never find this out. Then again, some students may crave the familiarity and continuity that they think going on in Latin might bring. These students are not inevitably disappointed by what they find, but often they are and, in any case, they seldom make the best students. Continuing students do well only if they stay with the subject because they love it, and if they open themselves to new approaches rather than clinging to the familiar.

The view expressed here is no doubt too schematic, but I think it is basically right, at least for a large number of programs at both levels. Less traditional sorts of high school and undergraduate programs lead to other sorts of frustration. If a student's high school training stressed cultural literacy over linguistic competence, that student as an undergraduate may find himself unable to function at the level he expects. Conversely, if an exceptionally well-trained student enters a college or university with a small classics program designed principally for newcomers, it may offer that student no significant intellectual challenge. Both students will probably lose interest and turn their attention elsewhere.

For the situation to improve, we need two things. First, better communication between high school and undergraduate programs, and better advising based on that communication. College and university instructors need to talk to their colleagues in the schools, and high school teachers need to stay abreast of the philosophies and the implementations of those philosophies that characterize specific undergraduate programs. To rely on the general reputation of any program or its institution would be a mistake. Knowing the programs and, if possible, the people in those programs is essential. Second, all of us should lobby to make classical literature a larger part of the secondary school curriculum. I do not mean simply supporting Latin programs, another area in which efforts should be maintained and, if possible, 
increased. But in addition to this, we should see to it that a student's exposure to classics as literature is not limited to the obligatory prose translation of the Odyssey. The whole range of Greek and Latin literature could be exploited. And these units should not simply be delegated to the English department: with a bit of schedule juggling, a week of guest lectures on Chariton by the Latin instructor might do wonders for the students' perception of classics. Showing students early in whatever way possible that Latin is not just a mental gymnasium for the young would give students a better idea of what they might expect from an undergraduate classics course, and might have immediate benefits for high school Latin programs as well.

University of Pennsylvania CW 92.1 (1998)

JOSEPH FARRELL joef@sermo.classics.upenn.edu

\title{
A M ERICAN・ACA DEMY $\bullet$ IN $\bullet$ R O M E
}

\author{
CLASSICAL SUMMER SCHOOL • JUNE 21 - JULY 31, 1999
}

Open to high school teachers and serious students of Latin, ancient history, and the classics, the Classical Summer School is designed to provide the student with a well-founded understanding of the growth and development of the ancient city of Rome and its immediate environs from the earliest times to the age of Constantine, through a careful study of material remains and literary sources. The daily visits to sites and museums will be preceded and accompanied by lectures intended to offer an introduction to the material and to place it within its context. Besides frequent excursions within Rome, the group takes field trips to major sites in Latium and Etruria such as Tivoli, Palestrina, Gabii, and the Alban Hills, Ostia, Cerveteri, Tarquinia and Veii. The director will be Professor Stephen L. Dyson, Department of Classics, State University of New York at Buffalo, 712 Clemens Hall, Buffalo, NY 14260 • (716) 645-2154, ext. 1114.

Classical Summer School tuition is $\$ 1,400$. Tuition, fees, room and board will total approximately $\$ 4,000$, not including airfare or personal expenses. Scholarships are available including a number of awards from regional and state classical associations. Please note that application deadlines for scholarships range from October 1998 to April 1999.

DEADLINE for Classical Summer School applications is March 1, 1999.

For applications, contact:

American Acaderny in Rome • 7 East 60 Street • New York, NY 10022-1001 • $212751-7200$

www.aarome.org 